\title{
Comparison of air pollutant standard index before and during the COVID-19 pandemic in DKI Jakarta
}

\author{
Dedy Hartono $^{1 *}$ Syamsul Maarif ${ }^{1}$, Deffi Ayu Puspitosari ${ }^{1}$, Iko Saikanti Ponangsera ${ }^{1}$, Jihan Fitriyanti $^{1}$ \\ ${ }^{1}$ Disaster Management Study Program, National Security Faculty, Republic of Indonesia Defense University. IPSC Sentul \\ Area, Bogor, West Java, Indonesia
}

\begin{abstract}
Clean air is a basic thing that is needed by living things. This makes clean air is very important for the continuity of life. Therefore, an air pollution standard index is needed to determine air quality based on the concentration of gas contained in it. As the State Capital which is the center of the economy, DKI Jakarta Province has an important air quality issue that needs to be controlled regularly. This research is a qualitative descriptive study of secondary data on the air pollutant standard index to compare the gas concentration parameters in the air before and during the COVID19 pandemic. The results of the analysis show that during the COVID-19 pandemic there was an increase in the "good and moderate" category days and a decrease in the "unhealthy and very unhealthy" category days compared to before the COVID-19 pandemic.
\end{abstract}

\section{Introduction}

DKI Jakarta Province is the economic center and the capital city of the Republic of Indonesia, which consists of five administrative cities with a dense population [1][2]. The high daily use of motorized vehicles, factory smoke, and other pollutants that tend to increase due to the impact of infrastructure development have resulted in low air quality in DKI Jakarta Province [3][4]. Modern urban life cannot be separated from various technologies and goods production systems to support people's welfare. But most of these things are the main causes of air pollution that we are not aware of.

Based on the air quality observation site aqicn.org on June 1, 2021, at 15:38, DKI Jakarta ranks 3 out of the top 100 countries with the worst air pollution [5]. The air quality in DKI Jakarta reaches the level of 134 US Air quality index which indicates the air in DKI Jakarta is unhealthy [5].

Air quality is a measure of the level of good or bad of a mixture of gases contained in the troposphere that is needed and affects the health of humans, living things, and other elements of the environment whose composition is not always constant [6][7]. Air quality is a basic need that is very important and needs to be considered because humans need oxygen to be able to continue to live [8], especially during the COVID-19 pandemic.

Data shows that several regions in Indonesia, including DKI Jakarta Province, have experienced an increase in positive cases of COVID-19 since it was first announced, both in the number of sufferers and the number of deaths [9]. COVID-19 As a new pandemic that is so complex and we do not fully understand, both medically such as viral compounds and their spread, health protocols, mitigation, vaccines, and treatment, but various other non-medical dimensions that we need to understand regarding the characteristics of this virus, such as air quality.

Based on the description above, this paper will try to analyze the comparison of the air pollutant standard index before and during the COVID-19 pandemic in DKI Jakarta Province. This needs to be analyzed further to provide a better understanding of the dynamics of handling and the impact of COVID-19 on air quality in DKI Jakarta Province.

\section{Study Method}

This study uses a qualitative research method with a descriptive approach in answering research problems. The research answers will be described based on secondary data on the air pollutant standard index [10][11][12] to compare the gas concentration parameters in the air before and during the COVID-19 pandemic in the discussion section, then conclusions will be drawn based on the results of the analysis that has been carried out by researchers.

\section{Result and Discussion}

\subsection{Concentration in 2019 and 2020}

Particulate Concentration $\left(\mathrm{PM}_{2.5}\right)$ is the concentration of

* Corresponding author: dedyhartonoaal@gmail.com 
airborne particles smaller than 2.5 microns (micrometers) [13]. In simple terms PM2.5 is a very small dust particle, even when compared to a strand of our hair split into 20 .

Because of its very small size, $\mathrm{PM}_{2.5}$ makes it dangerous, because it can enter the body to the deepest organs through the respiratory tract, and can even reach the lungs directly. More than that, $\mathrm{PM}_{2.5}$ can also reach into the blood vessels because of its very small size. So if the buildup continues to occur in the blood vessels, $\mathrm{PM}_{2.5}$ can also cause diseases such as heart disease and stroke. Another impact of $\mathrm{PM}_{2.5}$ is that this dust can affect pregnant women and the fetus they contain [14][15].

This is what makes $\mathrm{PM}_{2.5}$ concentration one of the mandatory benchmarks in looking at air quality in the environment. $\mathrm{PM}_{2.5}$ assessment can be categorized based on the threshold value. Threshold Limit Value (NAV) is the air pollution concentration limit that is allowed to be in the ambient air. NAV $\mathrm{PM}_{2.5}=65 \mathrm{gram} / \mathrm{m} 3$.

$\mathrm{PM}_{2.5}$ concentration in DKI Jakarta Province was carried out at 5 points representing the five administrative city areas of DKI Jakarta, namely Bundaran HI, Central Jakarta (DKI1), Kelapa Gading, North Jakarta (DKI2), Jagakarsa, South Jakarta (DKI3), Lubang Buaya, East Jakarta (DKI4), Kebon Jeruk, West Jakarta (DKI5). The results of the $\mathrm{PM}_{2.5}$ concentration in 2019 and 2020 in DKI Jakarta Province can be seen in Fig. 1.

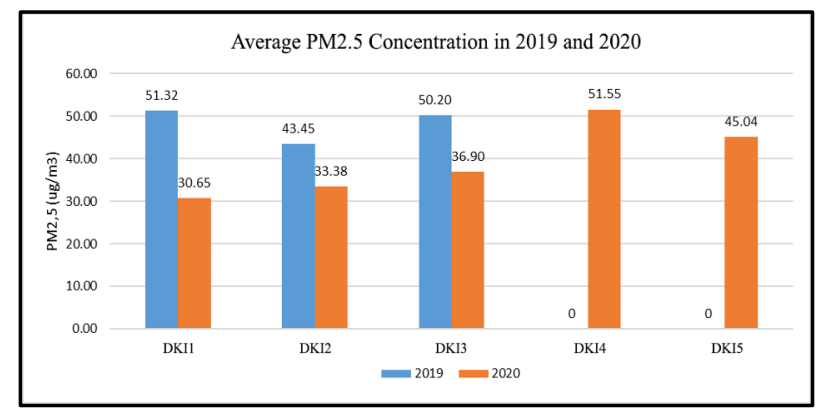

Fig. 1. Average $\mathrm{PM}_{2.5}$ concentration in 2019 and 2020

$\mathrm{PM}_{2.5}$ concentration in DKI Jakarta Province was carried out at 5 points representing the five administrative city areas of DKI Jakarta, namely Bundaran HI, Central Jakarta (DKI1), Kelapa Gading, North Jakarta (DKI2), Jagakarsa, South Jakarta (DKI3), Lubang Buaya, East Jakarta (DKI4), Kebon Jeruk, West Jakarta (DKI5). The results of the $\mathrm{PM}_{2.5}$ concentration in 2019 and 2020 in DKI Jakarta Province can be seen in Table 1.

Table 1. Average $\mathrm{PM}_{2.5}$ decline in 2020

\begin{tabular}{|c|c|c|}
\hline \multirow{2}{*}{ Station } & \multicolumn{2}{|c|}{ Decrease } \\
\cline { 2 - 3 } & $\boldsymbol{\mu g} / \mathbf{m}^{\mathbf{3}}$ & $\mathbf{\%}$ \\
\hline DKI1 & 20,67 & 40,28 \\
\hline DKI2 & 10,07 & 23,19 \\
\hline DKI3 & 13,30 & 26,49 \\
\hline DKI4 & - & - \\
\hline DKI5 & - & - \\
\hline
\end{tabular}

Table 1 informs that there was a decrease in the annual $\mathrm{PM}_{2.5}$ concentration in 2020 compared to 2019 . The decrease in $\mathrm{PM}_{2.5}$ concentration in DKI1 was $20.67 \mathrm{~g} / \mathrm{m} 3$ (40.28\%), DKI2 was $10.07 \mathrm{~g} / \mathrm{m} 3$ (23, $19 \%)$, DKI3 by
$13.30 \mathrm{~g} / \mathrm{m} 3$ (26.49 \%). However, the comparison of $\mathrm{PM}_{2.5}$ concentrations in 2019 and 2020 in DKI4 and DKI5 cannot be seen because there is no $\mathrm{PM}_{2.5}$ concentration data found in 2019.

In general, the decline in $\mathrm{PM}_{2.5}$ concentrations in 2020 occurred due to the work from home (WFH) program and large-scale social restrictions (PSBB) in DKI Jakarta Province, as shown in Fig. 2.

Fig.. 2. Comparison graph of the monthly average $\mathrm{PM}_{2.5}$ in 2019 and 2020

Fig. 2 explains that overall the monthly average concentration of $\mathrm{PM}_{2.5}$ in 2020 is lower than in 2019. When calculated during the COVID-19 pandemic in the period March to December 2020, the average $\mathrm{PM}_{2.5}$ at each monitoring station air quality can be seen in Table 2 .

Table 2. Average $\mathrm{PM}_{2.5}$ for the period March to December 2019 and 2020

\begin{tabular}{|c|c|c|}
\hline \multirow{2}{*}{ Station } & \multicolumn{2}{|c|}{ Decrease } \\
\cline { 2 - 3 } & $\mathbf{U g} / \mathbf{m 3}$ & $\mathbf{\%}$ \\
\hline DKI1 & 22,96 & 42,25 \\
\hline DKI2 & 7,56 & 16,83 \\
\hline DKI3 & 14,31 & 27,45 \\
\hline
\end{tabular}

Table 2 informs that in the period March to December 2019 and 2020 in DKI1 there was a decrease in $\mathrm{PM}_{2.5}$ concentration by $22.96 \mathrm{~g} / \mathrm{m} 3(42.25 \%)$, DKI2 by 7.56 $\mathrm{g} / \mathrm{m} 3$ (16.83\%), DKI3 of $14.31 \mathrm{~g} / \mathrm{m} 3(27.45 \%)$.

\subsection{CO Concentration in 2019 and 2020}

Carbon monoxide (CO) is a gas produced by a variety of processes, including the burning of coal, wood, and the use of fuel in motor vehicles. This gas is odorless, colorless, and cannot be tasted [16][17][18].

When a person is exposed to or inhales carbon monoxide gas, the blood's ability to bind oxygen is reduced. This is because $\mathrm{CO}$ gas is more easily bound to hemoglobin and then forms carboxyhemoglobin $(\mathrm{COHb})$. The more $\mathrm{COHb}$ that is formed, the less oxygen will be circulated throughout the body. As a result, the body will experience a lack of oxygen (hypoxia). Complications of carbon monoxide poisoning can cause brain damage, heart disease, and fetal compromise [19][20][21].

This is what makes the concentration of $\mathrm{CO}$ in the air one of the mandatory benchmarks in looking at air quality in the environment. $\mathrm{CO}$ assessment can be categorized based on the threshold value. Threshold Limit Value (NAV) is the air pollution concentration limit that is allowed to be in the ambient air. NAV CO $=25 \mathrm{gram} / \mathrm{m} 3$.

The concentration of CO in DKI Jakarta Province was carried out at 5 points representing the five administrative city areas of DKI Jakarta, namely Bundaran HI, Central Jakarta (DKI1), Kelapa Gading, North Jakarta (DKI2), Jagakarsa, South Jakarta (DKI3), Lubang Buaya, East Jakarta. (DKI4), Kebon Jeruk, West Jakarta (DKI5). The results of the 2019 and $2020 \mathrm{CO}$ concentrations in DKI Jakarta Province can be seen in Fig. 3. 


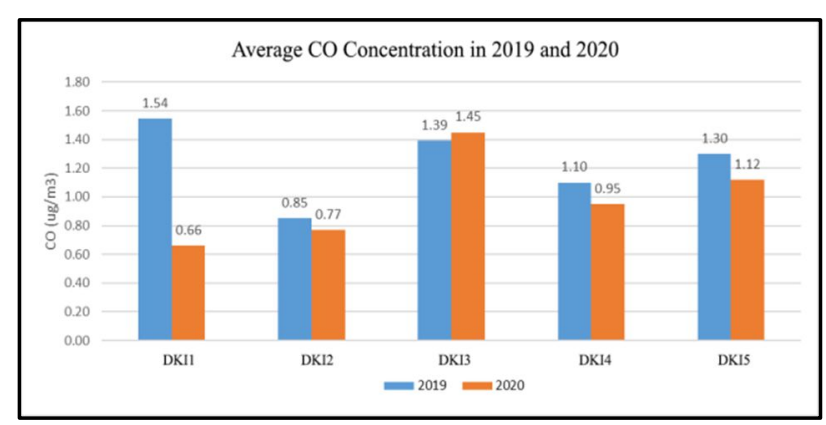

Fig. 3. Average CO concentration in 2019 and 2020

The result of CO concentration in DKI1 in 2019 was $1.54 \mathrm{~g} / \mathrm{m} 3$ and 2020 was $0.66 \mathrm{~g} / \mathrm{m} 3$, CO concentration in DKI2 in 2019 was $0.85 \mathrm{~g} / \mathrm{m} 3$ and 2020 was $0.77 \mathrm{~g} / \mathrm{m} 3$, the concentration $\mathrm{CO}$ in DKI3 in 2019 was $1.39 \mathrm{~g} / \mathrm{m} 3$ and 2020 was $1.45 \mathrm{~g} / \mathrm{m} 3$, CO concentration in DKI4 in 2019 was $1.10 \mathrm{~g} / \mathrm{m} 3$ and 2020 was $0.95 \mathrm{~g} / \mathrm{m} 3$, the concentration CO in DKI5 in 2019 was $1.30 \mathrm{~g} / \mathrm{m} 3$ and in 2020 it was $1.12 \mathrm{~g} / \mathrm{m} 3$. The decrease in the average concentration of CO in 2019 and 2020 can be seen in Table 4.

Table 4. 2020 average CO reduction

\begin{tabular}{|c|c|c|}
\hline \multirow{2}{*}{ Station } & \multicolumn{2}{|c|}{ Decrease } \\
\cline { 2 - 3 } & $\boldsymbol{\mu g} / \mathbf{m}^{\mathbf{3}}$ & $\mathbf{\%}$ \\
\hline DKI1 & 0,88 & 57,24 \\
\hline DKI2 & 0,08 & 9,59 \\
\hline DKI3 & $-0,06$ & $-4,32$ \\
\hline DKI4 & 0,15 & 13,64 \\
\hline DKI5 & 0,18 & 13,70 \\
\hline
\end{tabular}

Table 4 informs that there was a decrease in the annual CO concentration in 2020 compared to 2019. The decrease in CO concentration in DKI1 was $0.88 \mathrm{~g} / \mathrm{m} 3$ (57.24 \%), DKI2 was $0.08 \mathrm{~g} / \mathrm{m} 3$ (9.59 \%), DKI3 of -0.06 $\mathrm{g} / \mathrm{m} 3(4.32 \%)$, DKI4 of $0.15 \mathrm{~g} / \mathrm{m} 3$ (13.64 \%), DKI5 of $0.18 \mathrm{~g} / \mathrm{m} 3(13.70 \%)$. However, the CO concentration in DKI4 in 2020 has increased by $0.06 \mathrm{~g} / \mathrm{m} 3$ (4.32\%) compared to the previous year.

In general, the decline in CO concentrations in 2020 occurred due to the work from home (WFH) program and large-scale social restrictions (PSBB) in DKI Jakarta Province, as shown in Fig. 5.

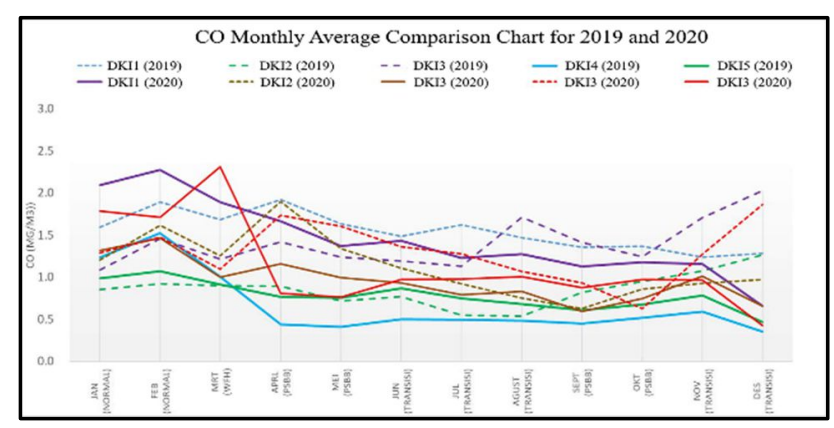

Fig. 5. Comparison graph of monthly average CO in 2019 and 2020

Overall, it can be seen that the average monthly CO concentration in 2020 is lower than in 2019. When calculated during the COVID-19 pandemic for the March to December 2020 period, the average CO at each air quality monitoring station can be seen in Table 5 .

Table 5. Average CO reduction for the period March to December 2019 and 2020

\begin{tabular}{|c|c|c|}
\hline \multirow{2}{*}{ Station } & \multicolumn{2}{|c|}{ Decrease } \\
\cline { 2 - 3 } & $\mathbf{U g} / \mathbf{m} 3$ & $\mathbf{\%}$ \\
\hline DKI1 & 0,98 & 65,34 \\
\hline DKI2 & 0,13 & 14,35 \\
\hline DKI3 & 0,13 & 9,21 \\
\hline DKI4 & 0,19 & 18,20 \\
\hline DKI5 & 0,27 & 21,56 \\
\hline
\end{tabular}

Table 5 informs that in the period March to December 2019 and 2020 in DKI1 there was a decrease in CO concentration by $0.98 \mathrm{~g} / \mathrm{m} 3(65.34 \%)$, DKI2 by 0.13 $\mathrm{g} / \mathrm{m} 3(14.35 \%)$, DKI3 of $0.13 \mathrm{~g} / \mathrm{m} 3(9.21 \%)$, DKI4 of $0.19 \mathrm{~g} / \mathrm{m} 3(18.20 \%)$, and DKI5 of $0.27 \mathrm{~g} / \mathrm{m} 3(21.56 \%)$.

\subsection{Trend ISPU Year 2019 and 2020}

In 2020 there was an increase in the number of days in the "Good and Moderate" category and a decrease in the days in the "Unhealthy and Very Unhealthy" category compared to the previous year (2019), as shown in Table 6.

Table 6. Comparison of ISPU in 2019 and 2020

\begin{tabular}{|c|c|c|c|c|}
\hline Air Pollutant & \multicolumn{2}{|c|}{$\mathbf{2 0 1 9}$} & \multicolumn{2}{c|}{$\mathbf{2 0 2 0}$} \\
\cline { 2 - 5 } Standard Index & $\sum$ & $\mathbf{\%}$ & $\sum$ & $\mathbf{\%}$ \\
\hline Good & 2 & 1 & 29 & 8 \\
\hline Moderate & 172 & 50 & 244 & 67 \\
\hline Not healthy & 183 & 48 & 90 & 24 \\
\hline Very Unhealthy & 8 & 2 & 3 & 1 \\
\hline Dangerous & 0 & 0 & 0 & 0 \\
\hline
\end{tabular}

In 2020 there was an increase in the number of days in the "Good and Moderate" category and a decrease in the number of days in the "Unhealthy and Very Unhealthy" category compared to the previous year (2019). Table 6 above informs that the Air Pollution Standard Index in 2019 with a good category of 2 days (1\%), moderate 172 days $(50 \%)$, unhealthy 183 days $(48 \%)$, very unhealthy 8 days $(2 \%)$, and dangerous 0 days ( $\%)$. In addition, the Air Pollutant Standard Index in 2020 has a good category of 29 days $(8 \%)$, moderate 244 days $(67 \%)$, unhealthy 90 days $(24 \%)$, very unhealthy 3 days $(1 \%)$, and dangerous 0 days $(0 \%)$.

\section{Conclusion}

The conclusion from the results that have been carried out shows that the COVID-19 pandemic has had a good impact on air quality in DKI Jakarta Province. This is evidenced by the decrease in PM2.5 concentration in the period March to December 2019 and 2020 in DKI1 by $22.96 \mathrm{~g} / \mathrm{m} 3$ (42.25\%), DKI2 by $7.56 \mathrm{~g} / \mathrm{m} 3$ (16.83 \%), and DKI3 of $14.31 \mathrm{~g} / \mathrm{m} 3(27.45 \%)$. The CO concentration in the same period showed a decrease in DKI1 by $0.98 \mathrm{~g} / \mathrm{m} 3$ (65.34 \%), DKI2 by $0.13 \mathrm{~g} / \mathrm{m} 3$ (14.35\%), DKI3 by 0.13 $\mathrm{g} / \mathrm{m} 3(9,21 \%)$, DKI4 was $0.19 \mathrm{~g} / \mathrm{m} 3(18.20 \%)$, and 
DKI5 was $0.27 \mathrm{~g} / \mathrm{m} 3$ (21.56\%). The decrease in PM2.5 and $\mathrm{CO}$ concentrations has provided benefits to the air pollutant standard index in DKI Jakarta Province in the form of increasing the number of days in the "Good and Moderate" category and decreasing the days in the "Unhealthy and Very Unhealthy" category.

\section{References}

1. W. Salim, B. Kombaitan, The rise and challenge of a capital City, 13 ,120-8, (Jakarta: 2009).

2. R. Setiowati, H. S. Hasibuan, R. H. Koestoer, Green open space masterplan at Jakarta Capital City, Indonesia for climate change mitigation IOP Conference Series: Earth and Environmental Science, 200, (IOP Publishing), 12042 (2018).

3. L. Dsikowitzky, W. S. A. Van der, F. Ariyani, K. J. Hesse, A. Damar, J. Schwarzbauer, Transport of pollution from the megacity Jakarta into the ocean: Insights from organic pollutant mass fluxes along the Ciliwung River Estuar, Coast. Shelf Sci. 215, 219-28 (2018).

4. G. Baum, H. I. Januar, S. C. A. Ferse, A. Kunzmann, Local and regional impacts of pollution on coral reefs along the Thousand Islands north of the megacity Jakarta, Indonesia PLoS One 10 e0138271 (2015).

5. IQAIR, World Air Quality Index Ranking | Air Visual (2021)

6. K. Mommens, N. Brusselaers, L. T. Van, C. Macharis, A dynamic approach to measuring the impact of freight transport on air quality in cities $J$. Clean. Prod. 240118192 (2019).

7. S. Schmitz, L. Weiand, S. Becker, N. Niehoff, F. Schwartzbach, V. Schneidemesser, An assessment of perceptions of air quality surrounding the implementation of a traffic-reduction measure in a local urban environment Sustain. Cities Soc, 41, 52537 (2018).

8. R. M. Harrison, Pollution: causes, effects, and control (Royal society of chemistry, 2015)

9. I. S. Ponangsera, R. K. Apriyadi, D. Hartono, W. Wilopo, Identification of the Characteristics of
COVID-19 on the Perception of the Number of Positive Cases, Recovered and Deaths Due to COVID-19 in Indonesia PENDIPA J. Sci. Educ, 5, 277-83 (2021).

10. Diskominfotik-Jakarta, Air Pollution Standard Index (ISPU) 2019 - Open Data Jakarta

11. K. Midander, K. Elihn, A Wallén, L. Belova, A. K. B. Karlsson, I. O. Wallinder, Characterisation of nano-and micron-sized airborne and collected subway particles, a multi-analytical approach Sci, Total Environ, 427, 390-400 (2012).

12. J. S. Apte, J. D. Marshall, A. J. Cohen, M. Brauer, Addressing global mortality from ambient PM2, 5 Environ. Sci. Technol, 49, 8057-66 (2015).

13. X. Ji, Y. Yao, X. Long, What causes PM2. 5 pollutions? Cross-economy empirical analysis from socioeconomic perspective Energy Policy, 119, 45872 (2018).

14. S. W. Ryter, D. Morse, A. M. K. Choi, Carbon monoxide: to boldly go where NO has gone before Sci. STKE 2004 re6-re6 (2004).

15. S. Mahajan, S. Jagtap, Metal-oxide semiconductors for carbon monoxide (CO) gas sensing: A review Appl. Mater. Today, 18, 100483 (2020).

16. A. Paliwal, A. Sharma, M. Tomar, V. Gupta, Carbon monoxide (CO) optical gas sensor based on $\mathrm{ZnO}$ thin films Sensors Actuators B Chem, 250, 679-85 (2017).

17. M. S. Al-Moamary, A. S. Al-Shammary, A. A. AlShimemeri, M. M. Ali, H. H. Al-Jahdali, A. A. Awada, Complications of carbon monoxide poisoning Saudi Med. J, 21, 361-3, (2000).

18. C-P. Lo, S-Y. Chen, K-W. Lee, W-L. Chen, C-Y. Chen, C-J. Hsueh, G-S. Huang, Brain injury after acute carbon monoxide poisoning: early and late complications Am. J. Roentgenol, 189, W205-11, (2007).

19. K. Betterman, S. Patel, Neurologic complications of carbon monoxide intoxication Handb. Clin, Neurol. 120, 971-9, (2014) 